\title{
Correction to: Blurring the Lines Between Civil Society, Volunteering and Social Movements. A Reflection on Redrawing Boundaries Inspired by the Spanish Case
}

\author{
Ramón A. Feenstra ${ }^{1}$ (D)
}

Published online: 20 February 2019

(C) International Society for Third-Sector Research 2019

\section{Correction to: Voluntas}

$$
\text { https://doi.org/10.1007/s11266-018-00056-6 }
$$

This paper should have appeared in the special issue presented here, but was previously published.

Publisher's Note Springer Nature remains neutral with regard to jurisdictional claims in published maps and institutional affiliations.

The original article can be found online at https:// doi.org/10.1007/s11266-018-00056-6.

\author{
Ramón A. Feenstra \\ feenstra@uji.es \\ 1 Jaume I University, Castellón de la Plana, Spain
}

